East African Journal of Science, Technology and Innovation, Vol. 2 (3): June 2021

This article is licensed under a Creative Commons license, Attribution 4.0 International (CC BY 4.0)

\title{
Substitution of Plastics with Organic Pots in Tree Seedlings Production for Sustainable Environmental Conservation
}

\author{
1MWANGI R W., 1WAGARA I N., 1KARIUKI S T.
}

${ }^{1}$ Department of Biological Sciences, Egerton University P.O. Box 536-20115, Egerton, Kenya

*Corresponding author: mwangiruth16@gmail.com

\begin{abstract}
The Mau Forest Complex, Kenya is the main water tower in the Rift Valley which has undergone extensive degradation and is in dire need of reforestation to avert desertification. Use of plastics in tree seedling production has contributed to environmental pollution, as these plastics are non-biodegradable, clog waterways, and poison livestock and wild animals. Moreover, in 2017, Kenya banned the use of single-use polythene bags and also outlawed manufacturing, sale as well as the distribution of polythene bags according to section 3 and 86 of the Environmental Management and Coordination Act (EMCACap 387). There is, therefore, need to identify alternatives to the plastics, which are degradable and environmental friendly. A study was done in the Mau Forest Complex with the aim of investigating if biodegradable seedling pots can be used as substitute for polythene tubes in tree seedling production as well as to determine the tree species that could rapidly form a denser canopy for use in reforestation. This study hypothesized that biodegradable containers (fibre baskets and bamboo tubes) could promote better growth of tree seedlings and offer more environmental-friendly benefits in comparison to the extensively utilized polythene containers. Seedlings of three tree species (Hagenia abyssinica, Juniperus procera and Olea europea subsp. africana) were planted in fibre baskets, bamboo tubes and polythene pots (control) in Gatimu and Mwisho wa Lami regions of the Mau Forest Complex, to determine their growth rate. A completely randomized design with six replicates was used and the results analyzed using SAS package software version 9. Fibre baskets gave the highest plant height $(106.7 \mathrm{~cm})$ with $H$. abyssinica in Gatimu while bamboo tubes $(94.7 \mathrm{~cm})$ and polythene pots $(88.3 \mathrm{~cm})$ did not show a significant difference at $p=0.05$ level. Olea europea subsp. africana generally demonstrated higher growth rate with all pots applied as treatments (fibre basket, bamboo tubes and polythene pots) than J. procera in Mwisho wa Lami. Fibre basket treatment gave the highest height and number of branches for the two plant species, (O. europea subsp. africana and $J$. procera) while bamboo tubes and the control treatments did not have any significant differences at $\mathrm{p}=0.05$. In this study, it was found that seedling bags made from plant fibres could be adopted in tree seedling propagation to replace the synthetic plastics for sustainable environmental conservation. Hagenia abysinica also is recommended for reforestation as it formed a quick dense canopy.
\end{abstract}

Keywords: Biodegradable; environmental-friendly; polythene; reforestation; seedling containers

Cite as: Mwangi et al., (2021). Substitution of Plastics with Organic Pots in Tree Seedlings Production for Sustainable Environmental Conservation. East African Journal of Science, Technology and Innovation 2(3)
Received: $\quad 17 / 08 / 20$

Accepted: 16/04/21

Published: 25/06/21 


\section{Introduction}

For a long time, Kenya has suffered serious damage of vegetation and forest cover, which results into successive degradation of extensive lands. Widespread clearing of trees and transformation of forested lands to agronomic land, industrialization, settlement expansion, the heightened consumption of tree and forest products by humans, as well as overgrazing has brought about environmental degradation. These are majorly associated with the ever-increasing human population as main determinants of the loss of the forests. Consequently, the major benefits drawn from these forest resources are inadequate and sometimes entirely scarce and rare (Cavender \& Donnelly, 2019). Frequently, transformations of naturally occurring forests into main land-use forms together with climate change have a negative influence on environmental as well as biological mechanisms (Zewdie \& Welka, 2015).

With the purpose of solving the problems associated with deforestation as well as meeting the ever-growing demands of the increasing population, it calls for sustainable utilization of forest resources and products. Conservation and prudent exploitation of the standing forests in addition to more planting of indigenous trees is of essence (Zewdie \& Welka, 2015). According to Cavender \& Donnelly (2019) agroforestry plays an important role in socio-economic development because trees planted on farms provide not only timber, fuel-wood, fodder, fruits, medicine, but also windbreaks, and a whole range of other economic, ecological and environmental benefits (Turner-Skoff \& Cavender, 2019).

The necessity of planting trees on farmlands is on the rise. It is difficult, nonetheless, for small-scale farmers to obtain high quality seedlings of their preferred trees when required - because the systems throughout the developing nations, which supply quality germplasm i.e. seeds, seedlings, cuttings and other propagules - are severely lacking. The timely supply of tree seedlings in sufficient amounts demands for promoting community as well as on-farm tree seedlings nurseries. These nurseries could be managed and maintained by individual growers, village women groups, youth groups, cooperatives or by other local community groups. These groups can offer tree seedlings to planters at a cheaper price, and in particular can cultivate the explicit tree species of interest to the local communities. The local tree nurseries may be treated as models for additional development of tree nurseries as well as providing incomegenerating opportunities (Dedefo et al., 2016).

For many years, tree seedlings production in forest nurseries, flower vendors' beds, botanic gardens and institutions has been using polythene tubes and plastic bags. These tubes are made of polyhydrocarbons, which are nonbiodegradable. There has been apprehension concerning the growing utilization of plastic products and their adverse effects on the public health as well as the environment in the longstanding. Synthetic polymers are nonbiodegradable and are made from resources that are non-renewable, require huge disposal volumes and when incinerated, they release dioxins (Hahladakisa et al., 2018). All these characteristics consist of extra costs of managing the solid waste, moved by dynamics along the whole lifecycle (Godfrey, 2019). The discarded polythene tubes accumulate in the environment, clog waterways and water collects in them when it rains thus become good breeding grounds for disease vectors including mosquitoes as well as other insects.

The buildup of wastes from plastic materials and products leads to environmental pollution (Shabani et al., 2015), which manifests in the environment through various avenues. One major leading problem is the decline of natural environmental magnificence as well as the death of domesticated and wild animals after ingesting the plastic materials (Adane \& Muleta, 2011; Moharam \& Maqtari, 2014). Cities and towns of 
developing countries are experiencing a common problem of blockage of sewerage systems. This generates obscene odours as well as creating conducive environments for disease vectors such as mosquitoes in addition to other insect vectors. These vectors have a capacity of spreading various diseases including dengue fever, encephalitis, Zika virus in addition to malaria and elephantiasis (Ramaswamy \& Sharma, 2011). The blockage also consequently results to overflowing of water and flooding during rainy seasons. When plastic wastes find their way into agrarian fields, they decrease water percolation in addition to appropriate soil aeration and these plastics can persist in the soil for thousands of years without decomposition by microorganisms, sunlight or other climatic forces. The accumulation of the plastic wastes reduces productivity in such fields (Macur \& Pudlowski, 2009).

Notwithstanding the noteworthy universal advances in managing, treating, recycling and reusing synthetic plastics in the recent times, the largest portion of plastic waste still conceivably culminates into dumping sites or is openly incinerated, releasing carbon monoxide (CO) and carbon dioxide $\left(\mathrm{CO}_{2}\right)$ (Groh et al., 2019). Thus, health threats of synthetic plastics arise from ingestion, as well as from destroying or disposing them through incineration. Incineration causes pollution to water, air as well as environment by exposing communities to noxious compounds such as carcinogenic substances.

Recycling these synthetic wastes is a difficult task by itself, besides the fact that plastic wastes discarded into environment certainly do not break down, thus aggravating the situation. With time, these plastics break down forming very small fragments, which cannot be decomposed by microorganisms found within the soil. Their buildup through the years increases soil toxicity. The toxic substances in the soil cause antagonistic effects on plants, animals as well as the microorganisms depending and thriving on such soils (Thompson et al., 2009).

In 2017, Kenya banned the use of single-use plastic bags after a presidential directive according to section 3 and 86 of the Environmental Management and Coordination Act (EMCACap 387), which outlawed the use, manufacture, importation and distribution of all polythene bags used for commercial and household packaging (Kenya Gazette Notice No. 2356; UN Environment Programme, 2020). This ban aimed at encouraging the adoption of the 'refuse, rethink, remanufacture, and recycle' environmental friendly options (Oguge, 2019). This ban places enormous pressure on the people who raise tree nurseries to seek for alternative seedling pots to support tree planting.

Biodegradable seedling pots enable direct transfer of seedlings into the soil without interfering with the seedlings' roots. Furthermore, this approach generates little or no solid waste whatsoever, compared to the use of plastic pots. Within this scheme, the seedling pot is transplanted together with the seedling, (i.e. the seedling pot is not removed) and consequently, the environmental dynamics in the soil such as microorganisms, moisture and temperature, are not interfered with (Nechita et al., 2010). After transplanting, the biodegradable container begins to break down, providing room for the roots to infiltrate through the walls (Guragain et al., 2015).

The aim of this study was, therefore, to determine which biodegradable seedling pots gave the best seedling growth and vigour and investigate which tree species grew faster and formed the highest number of branches for reforestation of the Mau Forest Complex.

\section{Materials and Methods}

\section{The study site}

The current study was carried out in Gatimu and Mwisho wa Lami regions within the Mau Forest Complex, Kenya. These sites are located on the Eastern Mau, one of the five main forest reserves of Mau Forest Complex. The complex is the largest Kenyan closed-canopy forestry ecosystem and the biggest native montane forest within East Africa, which stretches through 400,000 hectares. Site $1\left(00^{\circ} 38.862 \mathrm{~S}, 036^{\circ} 01.467 \mathrm{E}\right)$ was located in Sururu Forest, Gatimu area (2716 m above sea level) where the forest cover is dense. Site 2 $\left(00^{\circ} 37.089 \mathrm{~S}, 036^{\circ} 00.012 \mathrm{E}\right)$ was located in Sururu Forest, Mwisho wa Lami area $(2814 \mathrm{~m}$ above sea level) where vegetation has a patchy cover. The forest complex experiences bimodal type of rainfall where the long rains typically start in 
early April whereas the short rains commence in the month of November, even though this weather pattern has become inconsistent in recent times due to climate change. Mau forest is located within the greater Kenyan Rift Valley, a region where most people practice small-scale agriculture as the chief economic activity. The forest reserve was selected mainly because: (i), it harbors and forms a characteristic indigenous community of plants; (ii), a varied assortment of seeds from indigenous tree species can be collected from there; (iii), the nurtured seedlings can be utilized in restoration of the buffer zone of the forest reserve as well as the degraded land.

\section{Determination of the preferred plant species among farmers}

A questionnaire was administered to two groups of farmers at Gatimu and Mwisho wa Lami to determine their preferred plant species. A total of fifty farmers in both locations were asked to rank tree species which they wished to plant on their farms. The tree ranking by individual farmers was then collectively compiled to rank the trees of choice within each of the study sites. The farmers ranked ten plant species out of which they selected Hagennia abyssinica, Olea europea subsp africana, and Juiperus procera based on the tree species which grew faster and naturally in the area as well as on the ecological and economic benefits of the tree species (Sitienei et al., 2015).

\section{Seedling production in the nurseries}

Seeds of $H$. abyssinica, O. europea subsp. africana, and J. procera were collected from the forest. Unique numbers were labeled on pieces of plastics and were used in tagging thirty mature trees, with samples of ten trees for each species in the study. The unique numbers tagged on the trees were reproduced on small pieces of paper that were then folded and dropped into a container, were thoroughly mixed and only three papers were picked at random representing each tree species. Seeds for raising seedling nurseries were obtained from these selected trees. This procedure was followed in an effort to eliminate biasness. A total of 90 mature seeds (without any disease symptoms or defects) representing each species were picked, and this made 270 seeds in total for the three tree species. These seeds were then properly dried under shade to the recommended moisture content. They were then directly sown in polythene bags, fibre baskets (Plate 1) and bamboo tubes (Plate 2), which had a combination of sand, forest soil and local topsoil in the ratio of 1:2:4, respectively. Each seedling pot was sown with a seed from each of the three tree species. The size of the seedling bags whether polythene, fibre basket or bamboo tubes was approximately $15 \mathrm{~cm}$ and $8 \mathrm{~cm}$ in height and diameter respectively. The polythene seedling bags served as control. All containers that were seeded were given similar treatments in terms of hardening and weeding practices as well as watering and shading exposure. Although all seedlings were given similar treatments, it was noted that biodegradable pots required frequent watering because they dried faster compared to polythene pots.

During the first month of planting the seeds, the nurseries were protected against the adverse effects of direct wind and sunlight by covering the nursery beds using grass and straw. Therefore, the seedling nurseries were raised under restricted conditions with only 50\% direct sunlight. The amount of direct sunlight was gradually increased and shade decreased as tree seedlings continued to grow. To conserve moisture in the soil, watering of seedlings was done two times a day; early morning and late evening. Manual weeding was done on the nursery beds. Hardening of the seedlings was achieved when they were exposed to direct sunlight, by removing the cover of grass and straw in addition to reduction of the watering regime before field transplanting. A completely randomized design (CRD) with 30 replicates for each seedling pot was the experimental design used. 

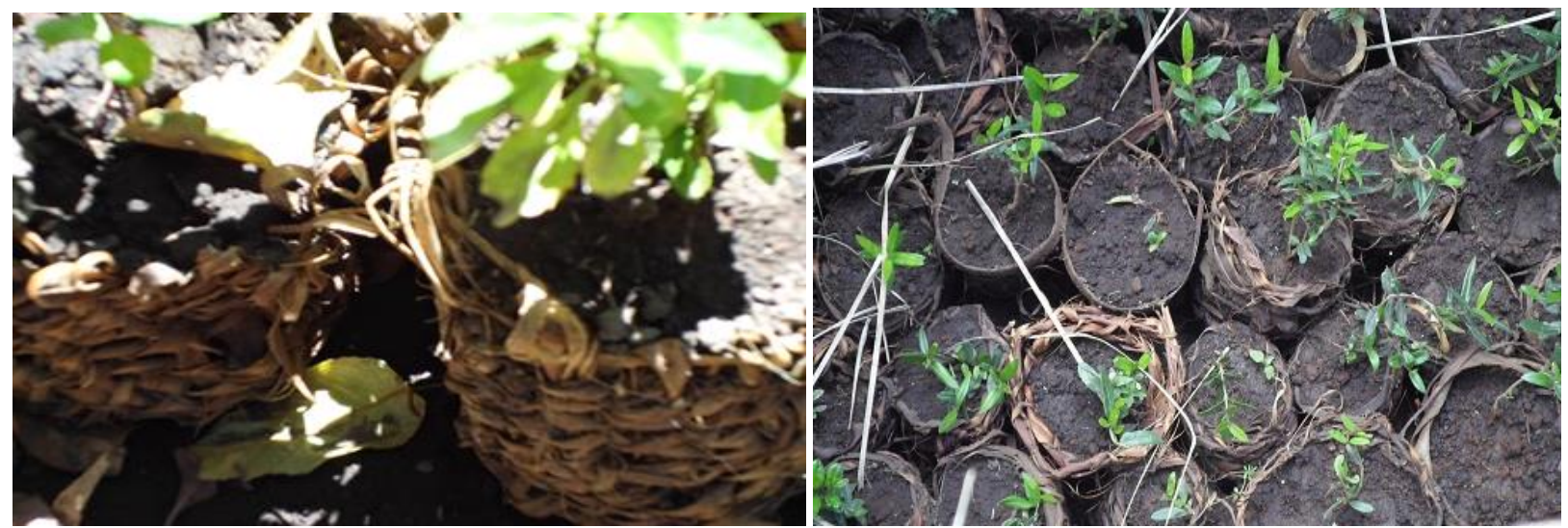

Plate 1. Fibre basket biodegradable seedling pots
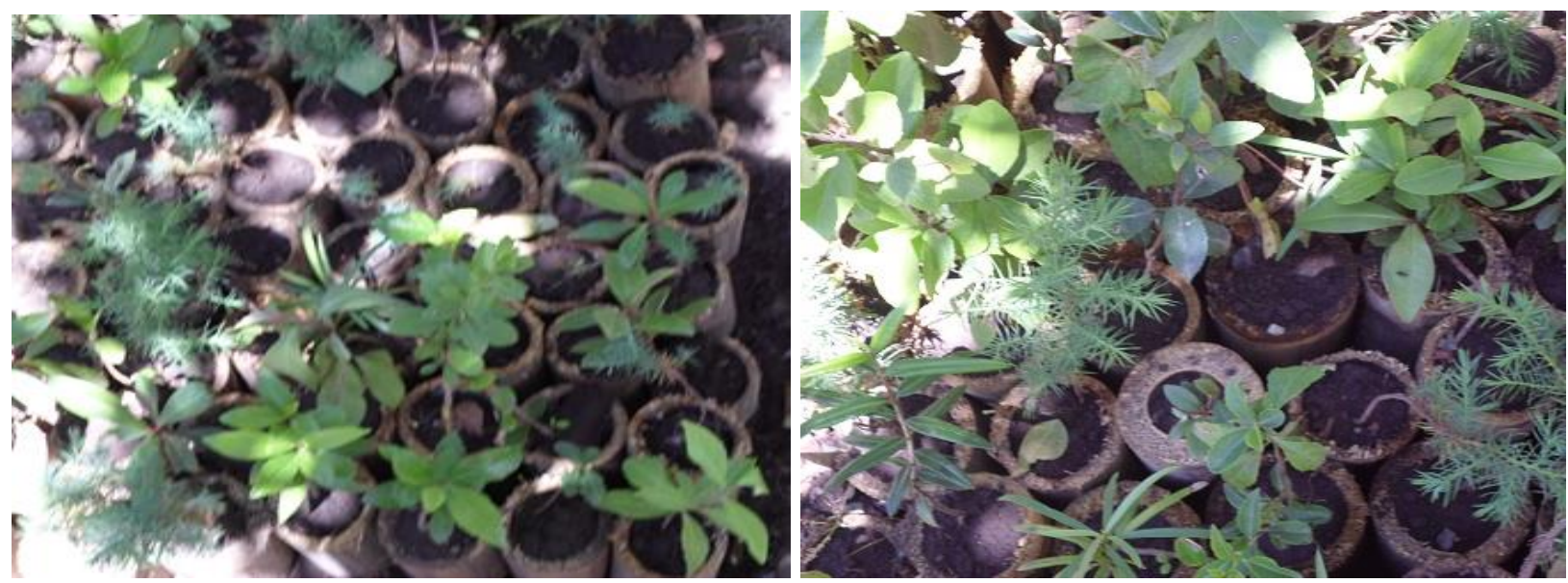

Plate 2. Bamboo biodegradable seedling tubes

\section{Field establishment of the seedlings in Gatimu and Mwisho Wa Lami}

This experiment was done to determine which of the three seedling bags (fibre baskets, bamboo tubes and polythene bags) resulted in the best tree growth. The tree species planted in Gatimu was H. abyssinica according to the farmers' choice. The experiment was set up in the month of November just after the onset of the short rains. The field was prepared a week prior to planting the seedlings. In the field, the holes for planting the seedlings were dug $30 \mathrm{~cm}$ and $8 \mathrm{~cm}$ in depth and diameter respectively. The plot size and dimensions were $6.5 \times 6 \mathrm{~m}$. Each plot had six rows of tree seedlings. Each row had a line of four trees, with two rows of control, two rows of fibre baskets and two rows of bamboo tubes and therefore, a plot consisted of 24 tree seedlings. The space between two seedlings in a row was $1 \mathrm{~m}$ whereas rows on the same plot were separated by $1 \mathrm{~m}$. The distance between two plots was $2 \mathrm{~m}$. Treatments (the three seedling bags)

were arranged in a CRD design, and were replicated six times. In Mwisho wa Lami there were two plots; one plot was planted with $O$. europea subsp. africana and the other with $J$. procera. The polythene bags used in raising seedlings as the control were removed before transplanting whereas those seedlings raised in self-decomposing pots (fibre baskets and bamboo tubes) were planted with the containers. Data on tree height and number of branches was recorded on a monthly basis over a period of seven months. The data was analyzed using SAS package version 9.0 and treatments means were separated using LSD at $\mathrm{p}=0.05$.

\section{Results}

\section{Seedling germination, survival and watering regime}

There was a $90 \%$ germination of the seedlings in all the seedling containers for the three plant species. The seedlings established in polythene 
tubes did not dry up as fast as those in fibre baskets and bamboo tubes. It was therefore, observed that seedlings raised in the biodegradable pots required more frequent watering compared to those raised in polythene tubes. All the seedlings survived although the growth rate varied among the treatments with those in polythene tubes acquiring the highest height.

\section{Growth rate of Hagenia abyssinica seedlings in} the field after transplanting

At the time of transplating, seedlings of $H$. abyssinica that had been raised in polythene bags showed the maximum growth in terms of height
$(19 \mathrm{~cm})$ as well as number of branches $(9)$ whereas those raised in fibre baskets and bamboo tubes had the least growth $(15 \mathrm{~cm}$ and $14.7 \mathrm{~cm}$ respectively). The seedlings raised using the biodegradable pots (fibre baskets and bamboo tubes) demonstrated comparable growth characteristics. Thirty days after transplanting, the mean number of branches for all treatments did not show any significant differences (Figure 1). However, height of the seedlings in biodegradable bags was significantly higher $(p=$ 0.05 ) when compared to the height of seedlings raised in polythene tubes (Figure 2).

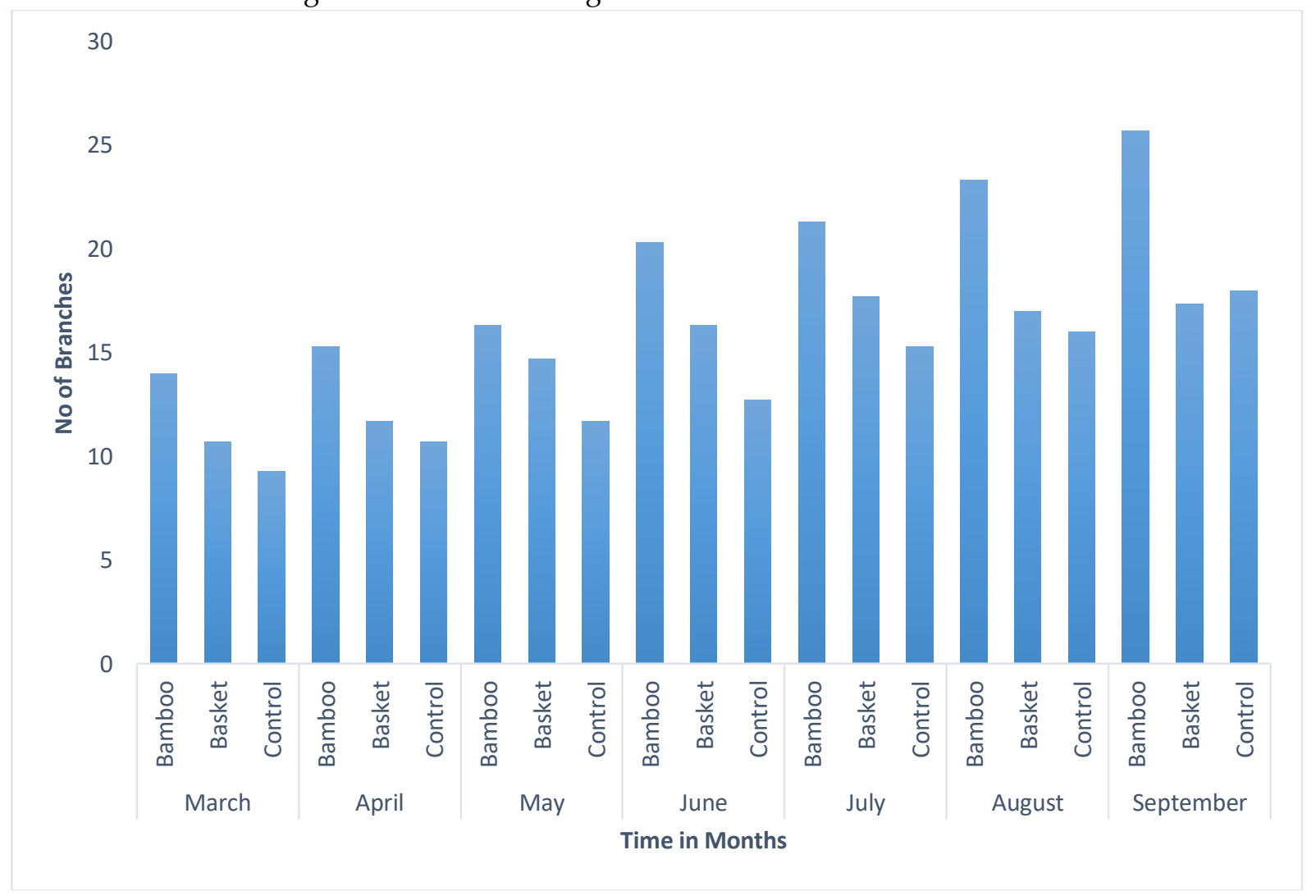

Figure 1. Mean branches of Hagenia abyssinica through the seven months in the field in Gatimu 


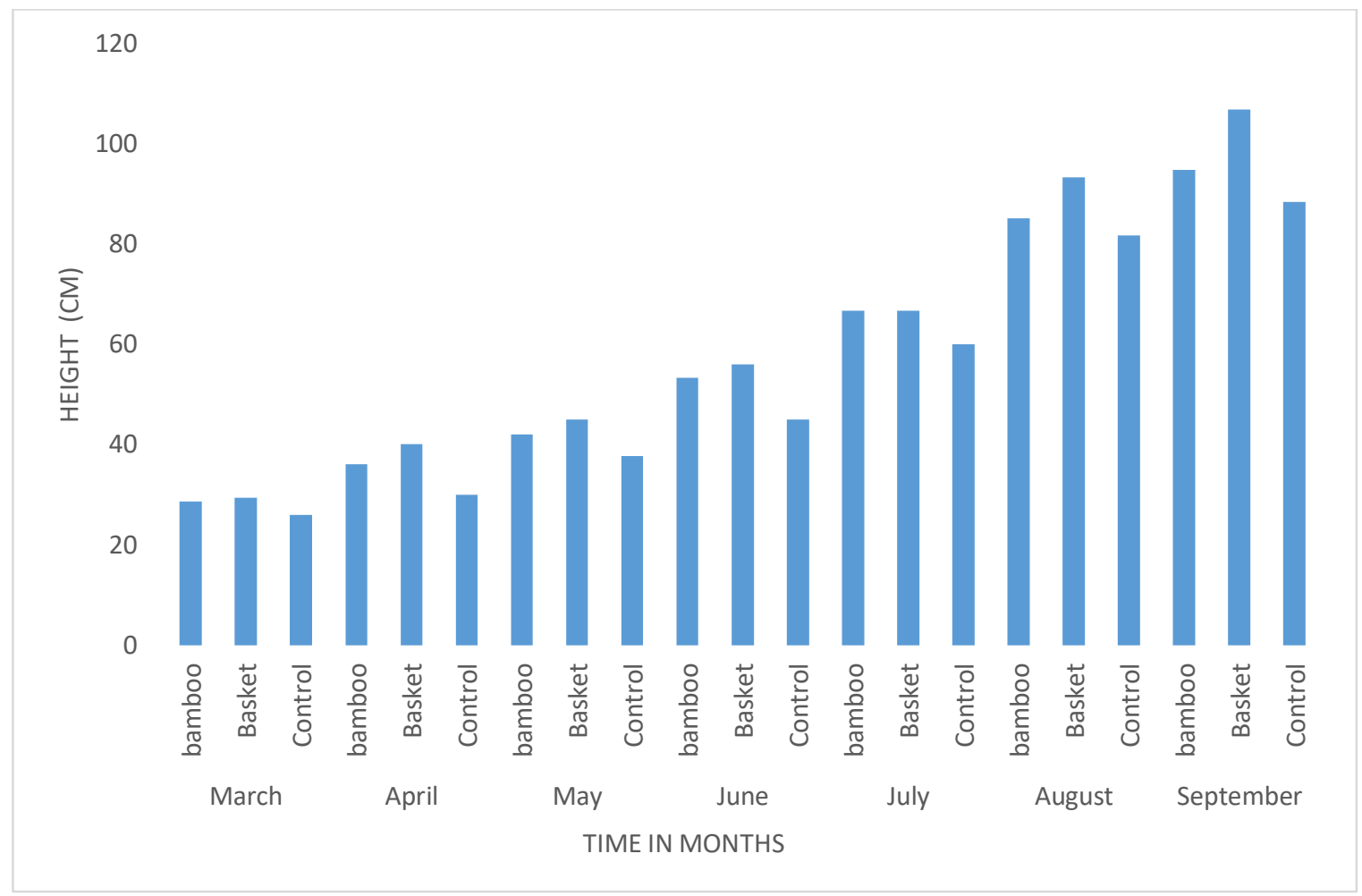

Figure 2. Mean height of Hagenia abyssinica through the seven months in the field in Gatimu

Three months after transplanting, seedlings in the biodegradable pots did not show much difference; however, they were significantly different from those in the polythene tubes
(Figure 1 and 2). Seedlings raised in bamboo tubes produced a higher number of branches than those in fibre baskets (Figure 2). Generally, seedlings raised in the biodegradable containers outgrew those raised in polythene bags four months after transplanting (Figure 3).

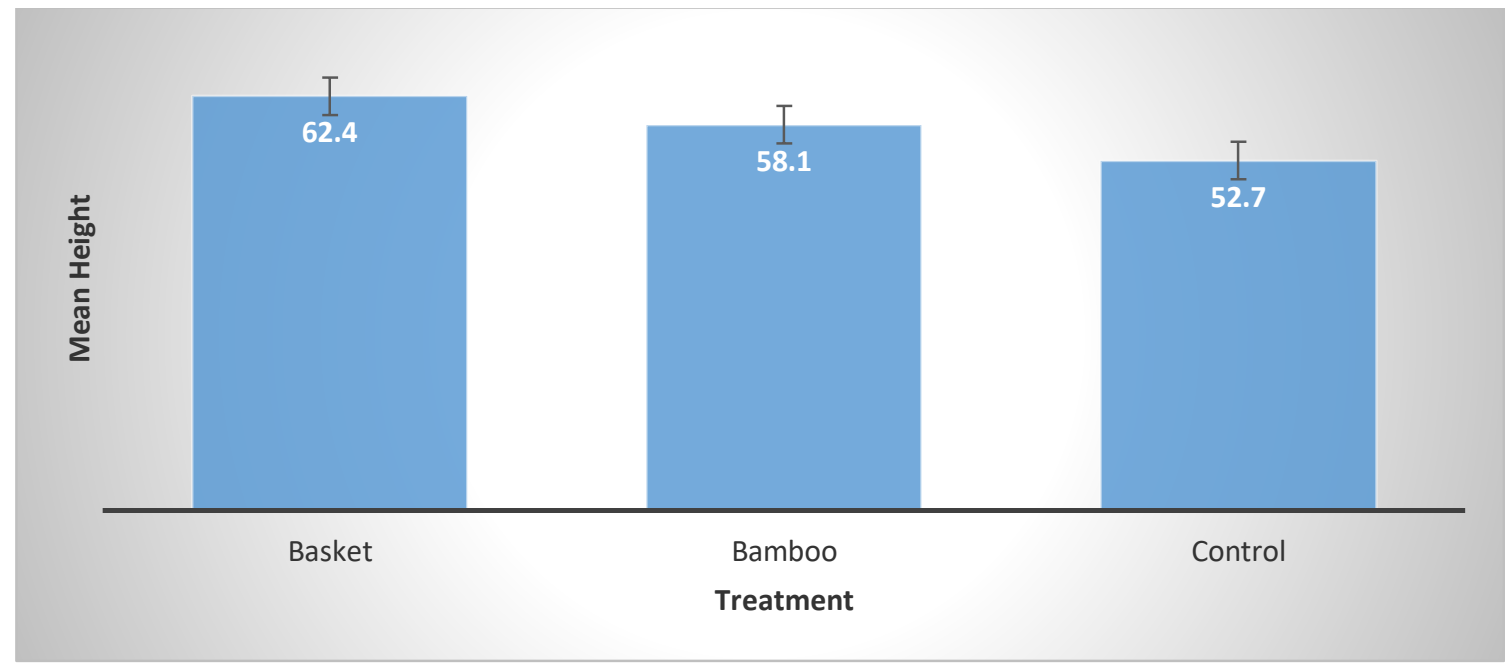

Bars indicate the standard error at $P \leq 0.05$

Figure 3. Height of Hagenia abyssinica in Gatimu 
Following seven months of seedlings' transplanting in the field, differences in growth patterns were observed in mean heights although the number of branches showed minor and nonsignificant differences $(p=0.05)$. The tree seedlings raised in polythene bags achieved the least height $(88.3 \mathrm{~cm})$ whereas the seedlings raised in biodegradable fibre baskets attained the highest height of $106.7 \mathrm{~cm}$. Bamboo tubes produced the highest number of branches throughout the seven months of field establishment with a mean of 25.7 branches in seventh month (Figure 2). Hagenia abyssinica formed a closed canopy after seven months of field establishment (Plate 3). Hagenia abyssinica attained the highest height $(106.7 \mathrm{~cm})$ but the lowest For Hagenia abyssinica, fibre baskets gave the best growth which was followed by bamboo and finally the control for both height (Figure 2) and number of branches at $\mathrm{p}=0.05$ number of branches (18) with fibre baskets.

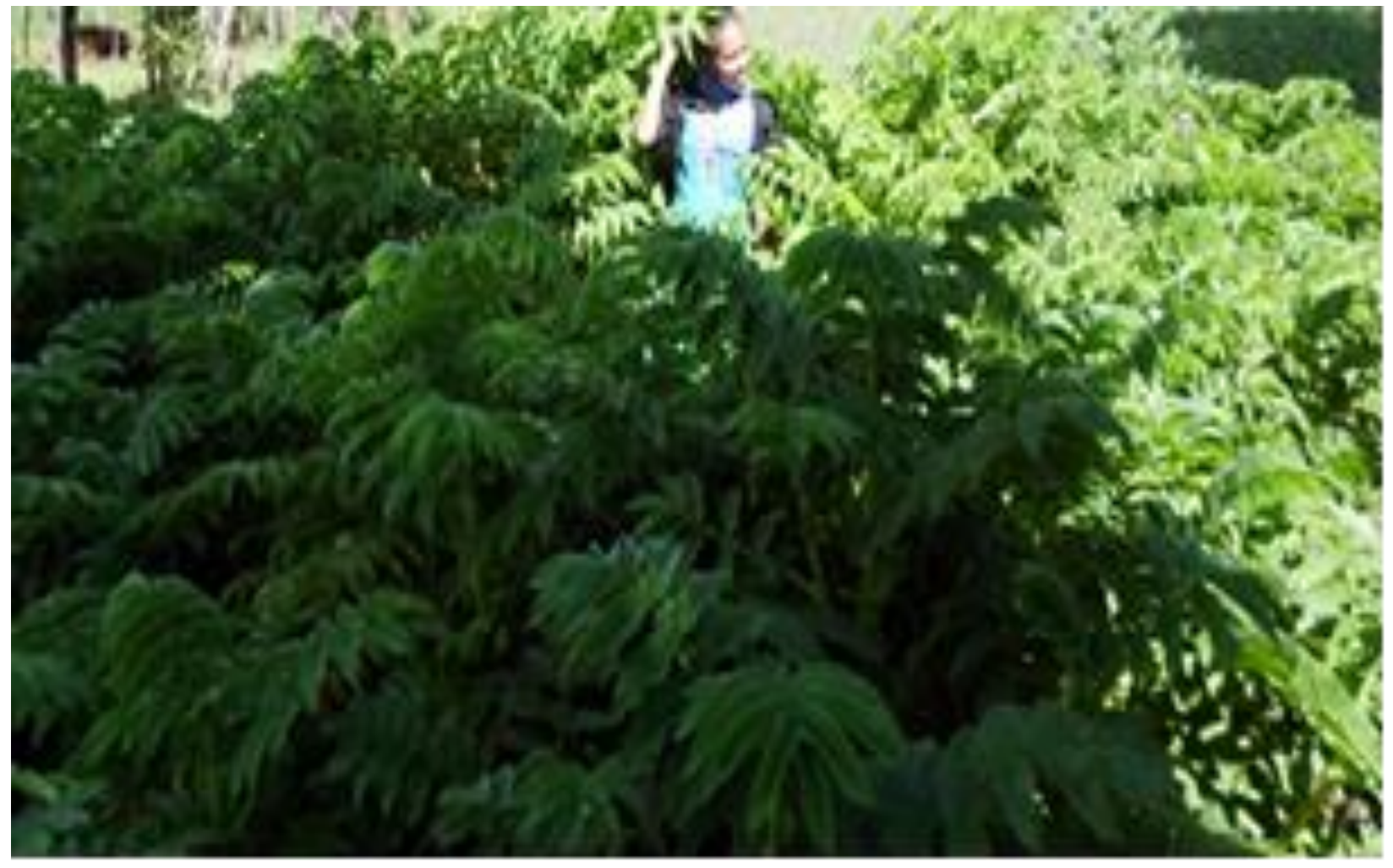

Plate 3. Hagenia abyssinica showing a closed canopy seven months after transplanting in the field

Growth rate of Olea europea subsp africana and Juniperus procera seedlings in the field after transplanting

The biodegradable pots did not show much significant differences on the mean height of Olea europea subsp africana throughout the seven months of field establishment (Figure 4). However, similar to $H$. abyssinica, there was significant difference with the seedlings raised in plastic pots. Fibre basket gave the highest number of branches with Olea europea subsp africana although there was no significant differences between bamboo tubes and control (Figure 5). Surprisingly, seedlings of Juniperus procera raised in plastic pots demonstrated greater height and higher number of branches compared to biodegradable pots and this trend persisted throughout the seven months of the field establishment (Figure $6 \& 7$ ). 


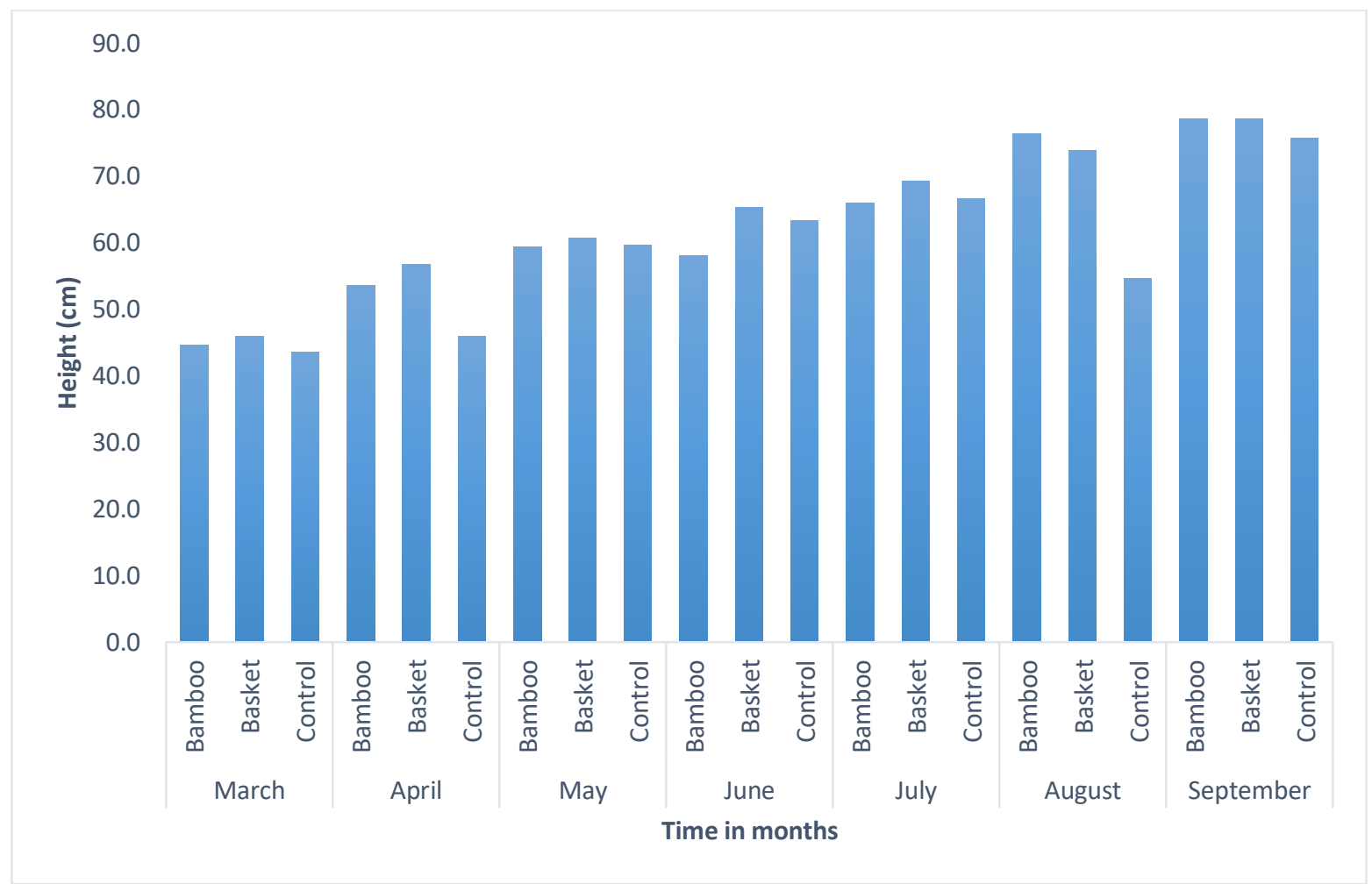

Figure 4. Mean height of Olea europea subsp africana through the seven months in the field in Mwisho wa Lami

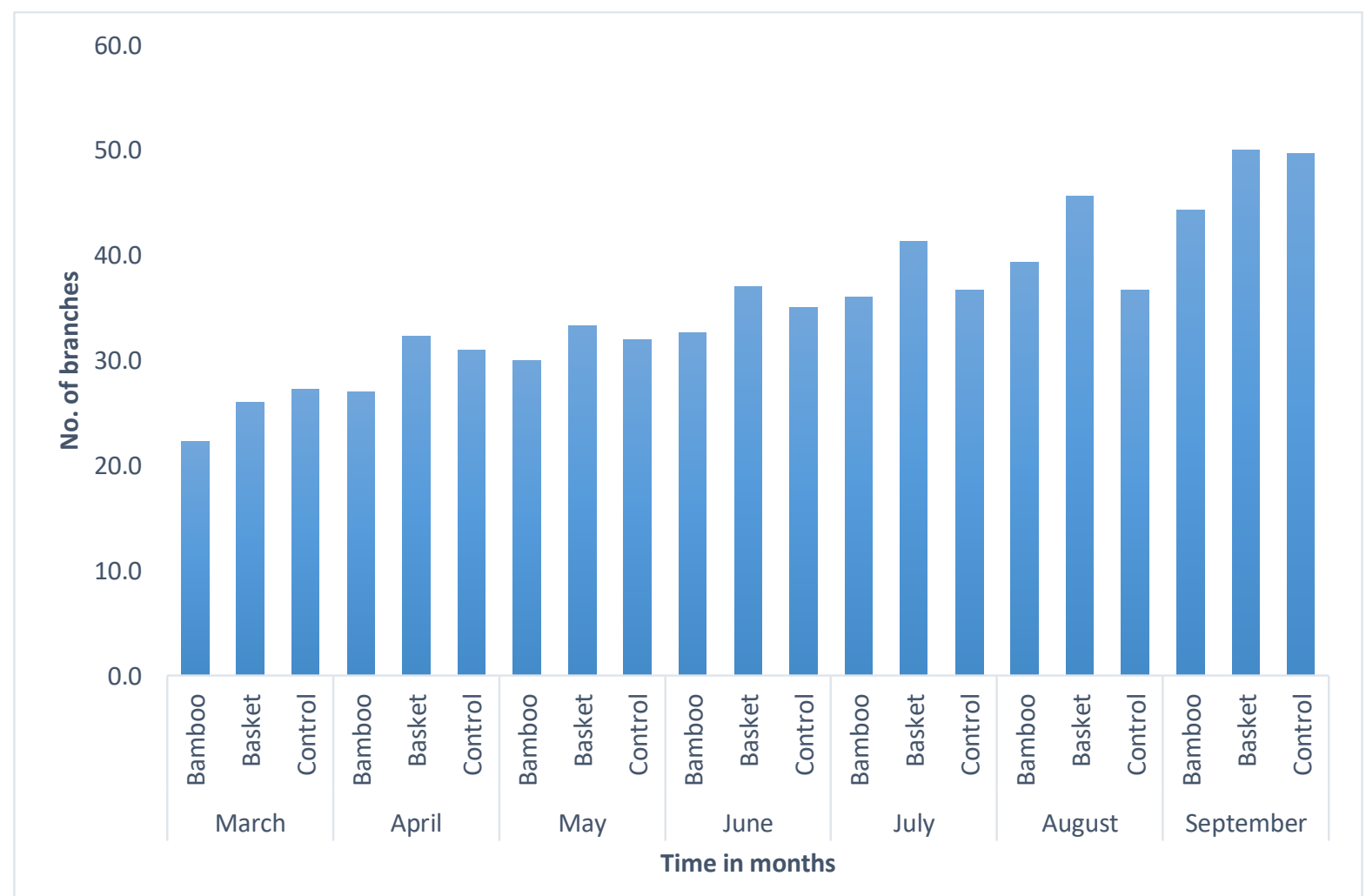

Figure 5. Mean branches of Olea europea subsp africana through the seven months in the field in Mwisho wa Lami 


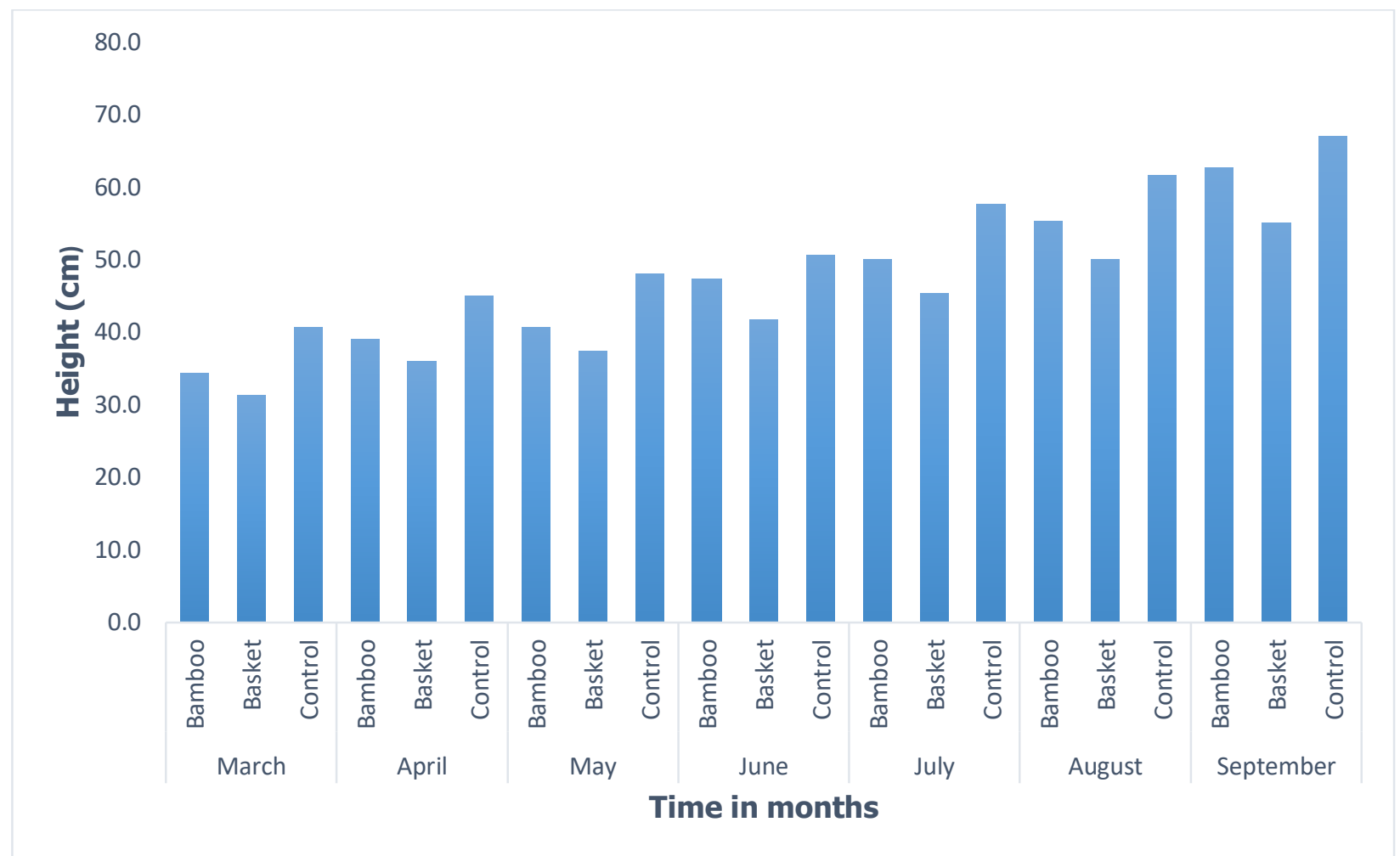

Figure 6. Mean height of Juniperus procera through the seven months in the field in Mwisho wa Lami

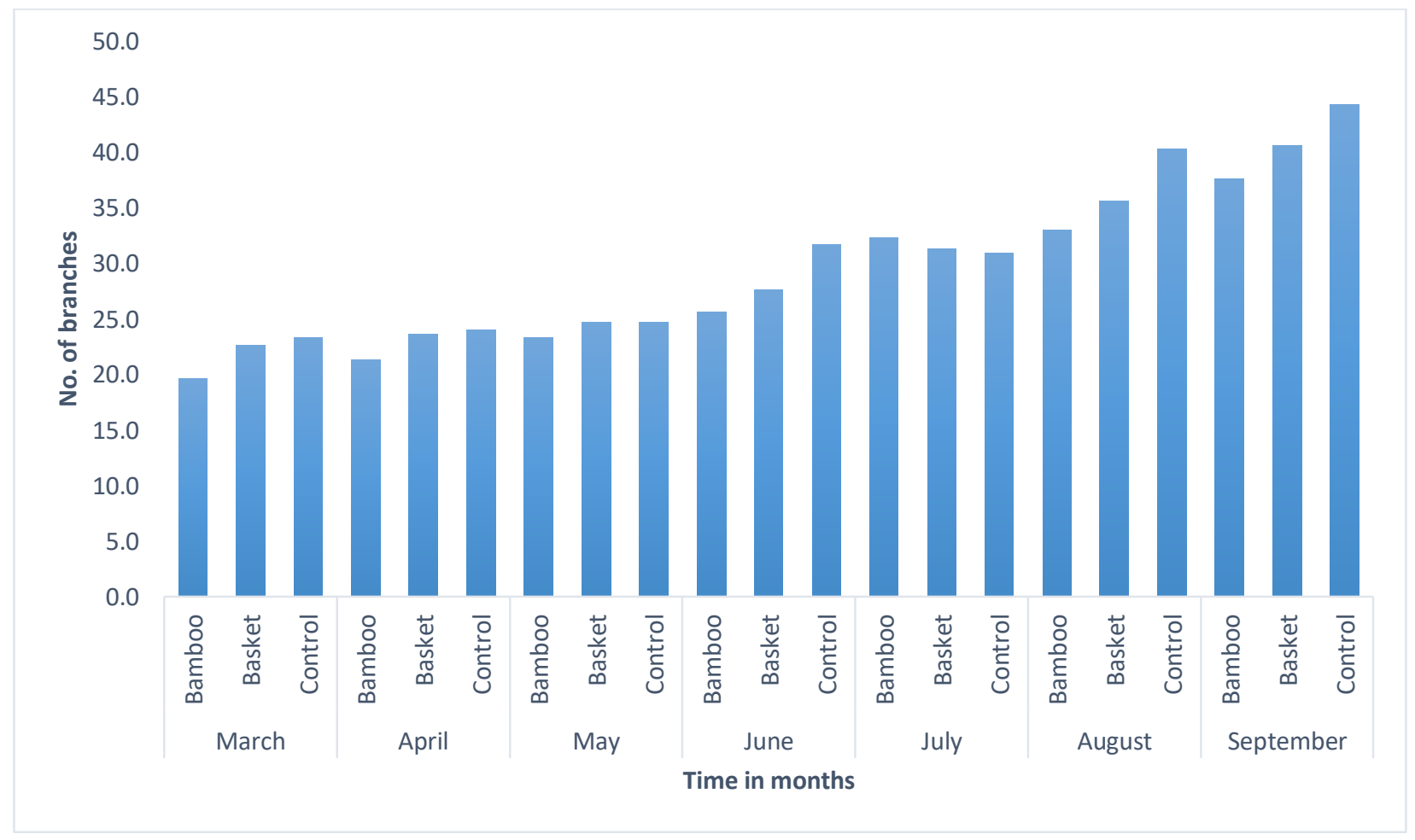

Figure 7. Mean branches of Luniperus procera through the seven months in the field in Mwisho wa Lami 
Juniperus procera demonstrated the lowest vigour as it had attained a height of $44.33 \mathrm{~cm}$ with the polythene bags, $37.7 \mathrm{~cm}$ with bamboo tubes and $40.7 \mathrm{~cm}$ with fibre baskets. There was no significant difference among the three seedling containers with this species at $p=0.05$. Olea europea subsp africana attained a height of $78.7 \mathrm{~cm}$ with fibre baskets which showed some significant difference $(p=0.05)$ when compared to the control treatment as shown in Figure 4. There were no significant differences in the height of seedlings raised in fibre baskets and bamboo tubes (Figure 8). Olea europea subsp africana produced the highest number of branches with all the seedling containers but there were no significant differences $(p=0.05)$ between the seedling containers.

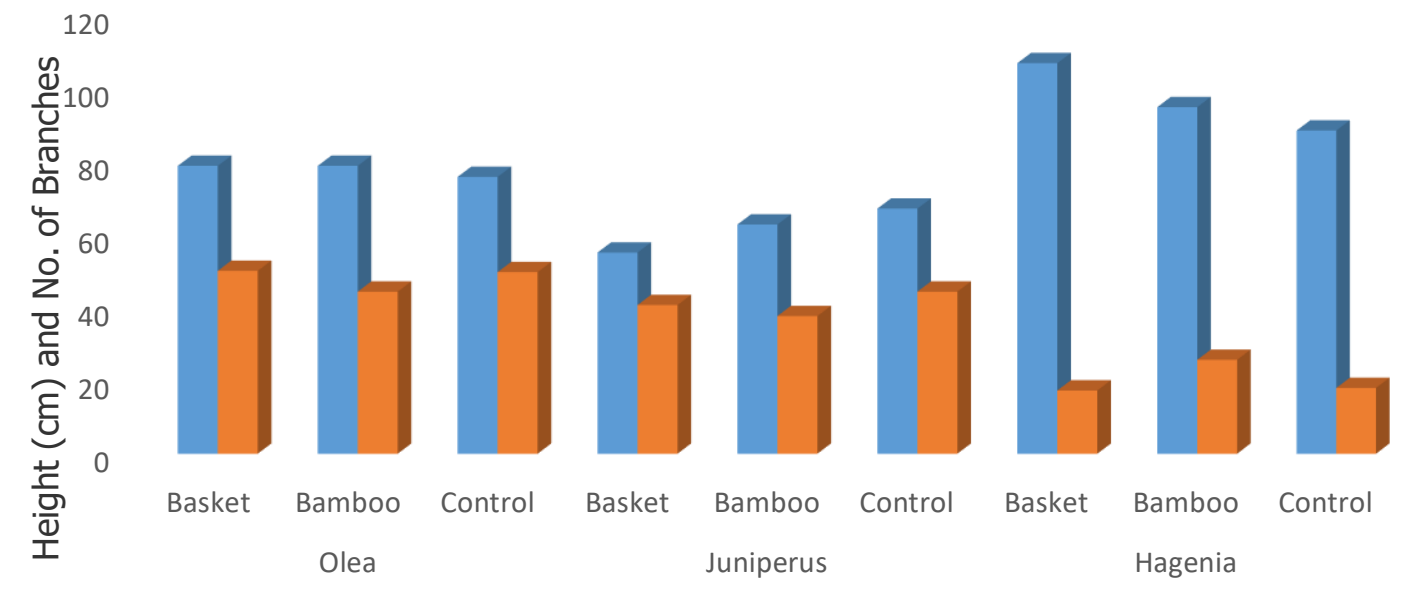

Treatment on the plant species

- Height Branches

Figure 8. Mean height and number of branches of the three plant species after seven months of field establishment in Gatimu and Mwisho wa Lami

\section{Discussion}

Results of the present study demonstrate that the three indigenous tree species (Hagenia abyssinica, Olea europea subsp africana and Juniperus procera) could be successfully propagated from seeds in seedling nurseries and thrive well when transplanted in the field. The three tree species demonstrated high germination rates of more than $85 \%$. The few seeds that did not germinate were probably because of defects in the seeds, infestation with pathogens/pests, they were not fully mature, or they were still undergoing seed dormancy. Seeds remain the most important initial resources for propagation of many important forest trees. Moreover, seeds as propagules are still used and are considered the cheapest and easiest, and the prevalent resources for different agroforestry and timber tree species (Nyoka et al., 2011). Largely, this is attributable to the fact that seeds are often easy to produce and handle (Mng'omba et al., 2007). Sufficient soil moisture is essential for a few months following transplanting. The farmers transplanted the seedlings during the onset of short rains which ensured sufficient moisture in the soil. Transplanting during the short rains was an effort of making the transplanting environment similar to environment before transplanting to reduce transplant shock. The seedlings had been acclimatized to full sunlight and thus did not suffer much transplant shock. This explains why all the transplanted seedlings survived after transplanting. Plants that are growing in the shade usually have a difficult time adjusting to full sunlight (Close et al., 2005). 
Seedlings established in the biodegradable fibre baskets and bamboo tubes required more frequent watering compared to those raised in polythene tubes under similar environmental conditions. This is because the fibre baskets had big holes that lost water and the bamboo tubes were open at the bottom, consequently losing the water supplied. This observation agrees with Wang et al., (2012) who reported that the Euonymus fortunei plants, on average required 35 times more water when raised in wood pulp and gallon paper containers than plants raised in the standard polythene tubes. These were results obtained from a four-month experiment conducted under outdoor conditions in Michigan.

Forest degradation and deforestation have caused extensive loss of biodiversity of plant species and environmental destruction in Kenya. To meet the growing demands of natural resource by the ever-increasing population as well as to resolve deforestation and the associated problems, the communities have no choice but to safeguard as well as prudently exploit the remaining forests (Yang et al., 2016). These remaining forests, alone, cannot meet the human needs; they are not adequate to achieve an environmental equilibrium. Therefore, considerable work must get underway to produce adequate numbers of superior seedlings in nursery bed settings. Such kind of work can increase the forest cover within a nation in order to alleviate deforestation problems (Zewdie \& Welka, 2015). The result of this study clearly demonstrate that the tree species employed in this study could potentially be applied to support the remaining forests and reafforest the degraded forests.

The results from this study confirmed the superiority of biodegradable bags made from plant materials over the polythene tubes in facilitating seedlings' transition from the nursery to the field. After transplanting, the seedlings raised in biodegradable pots were observed to grow faster, acquiring greater height and more branches. Contrasting to the polythene tubes, biodegradable pots stimulate better aeration and drainage, which facilitate and aid the roots to develop normally in the seedling nursery
(Negash, 1995; Nzimande et al., 2020). The seedlings' root system remains intact since biodegradable pots are not removed and thus do not distort the roots during transplanting. This greatly reduces the transplant shock and risk to the fragile seedling due to the root protection by the adhering growing soil. Use of biodegradable pots reduce transplanting cost and time, in addition to significantly reducing the volume of disposed containers and enhancing solid waste management. Plastic seedling containers constrain the aeration and growth of seedling roots within the nursery beds (Kim et al., 2020). When the seedlings are detached from the plastic bags and out-planted in the field, prolonged time is required for the roots to anchor into the ground since in most cases they may have coiled in the plastic bag. The coiling also interferes with absorption of water and nutrients from the soil as well as translocation of food substances to the roots because of deformation of the vascular bundles. This probably explains why the seedlings show limited growth vigour as they establish in the field (Muriuki, et al., 2014).

Results of the current study were in line with other researches carried out on various biodegradable seedling tubes. For instance, Muriuki et al., (2014) tracked and compared the vigour and growth of Calliandra calothyrsus seedlings raised using polytubes as well as four different kinds of decomposable seedling tubes from the nursery to the field. Three kinds of seedling tubes made from cellulose (EP, FP and $\mathrm{VP)}$ fibre sheaths of bananas, and polythene material were used in the experimental trials. Within the nursery beds, seedlings raised using polythene tubes demonstrated higher growth vigour compared to those raised in decomposable tubes by almost twofold. However, once these seedlings were transplanted into the field, the trend changed. They reported that the enhanced seedlings' performance in decomposable tubes became apparent and clear in the second month of transplanting. After four months of transplanting, the seedlings raised using the three kinds of decomposable tubes had outdone the seedlings raised in polytubes in growth and vigour. As the study came to an end after six months of transplanting in the field, the trend was maintained. This trend was clearly observed in the current study. 
The biodegradable tubes should degrade rapidly after seedlings are transplanted in the outdoor conditions to allow the young plant to root and penetrate the surrounding soil. The biodegradable tubes do not need to be removed when the seedling is being out-planted (Gerlach, 2007). The speed at which the containers biodegrade after transplanting is subject to the material making the container. The environmental factors include nitrogen, microbes, moisture, temperature, the $\mathrm{pH}$, and many other factors found in the soil. In the current study, the fibre baskets degraded faster and allowed the young plants to anchor adequately in the soil. Evans et al., (2010) reported that the highest decomposition of tubes was observed with Cow-pot TM, that was made using nitrogen and cellulose obtained from dairy manure. Moderate degradation was observed in wood pulp, rice straw and peat tubes. In the current study, the basket fibre contained high amounts of cellulose and nitrogen and thus had high rates of degradation. The lowest level of decomposition observed by Evans et al., (2010) was linked to coconut fiber tubes because they contained high lignin contents, likewise the bamboo tubes in the current study. The slower rate of degradation of bamboo tubes could cause root deformation and coiling, restricted nutrient and water movement as well as reduce capacity to effectively anchor (Ingram \& Nambuthiri, 2012). However, it was observed that as the roots

\section{References}

Adane, L. \& Muleta, D. (2011). Survey on the usage of plastic bags, their disposal and adverse effects on environment: a case study in Jimma City, Southwestern Ethiopia. Journal of Toxicology and Environmental Health Sciences, 3(8), 234248.

Cavender, N., \& Donnelly, G. (2019). Intersecting urban forestry and botanical gardens to address big challenges for healthier trees, people, and cities. Plants, People, Planet, 1(4), 315-322.

Close, D. C., Beadle, C. L., \& Brown, P. H. (2005). The physiological basis of containerised tree seedling 'transplant shock': a continued to grow, the bamboo tube split into two due to the force exerted by the expanding root density.

\section{Conclusion}

The fibre basket pots gave the highest seedling growth rate and vigour and can, therefore, be used as substitute for the polythene bags for seedling production and reforestation. Similarly, $H$. abyssinica had the highest growth rate and formed closed canopy faster followed by $O$. europea subsp. africana, and therefore the two indigenous tree species can be recommended for reforestation of Mau Forest and other degraded forests.

The authors recommend the use of biodegradable tubes in seedling production to eliminate the use of polyhdrocarbon bags, which cause environmental pollution. They also recommend reforestation of degraded forests using $H$. abyssinica because the species has the ability of forming a closed canopy faster.

\section{Acknowledgement}

We acknowledge Mushroom Initiative Limited of Hong' Kong' for supporting this work financially, Mr. John Ndung`u, and Mr. John Mucheru for providing the pieces of land to carry out this work.

review. Australian Forestry, 68(2), 112120.

Dedefo, K., Derero, A., Tesfaye, Y., \& Muriuki, J. (2016). Tree nursery and seed procurement characteristics influence on seedling quality in Oromia, Ethiopia. Forests, Trees and Livelihoods, 5(3), 1-15.

Evans, M. R., Taylor, M. \& Kuehny, J. (2010). Physical Properties of Biocontainers for Greenhouse Crops Production. HortTechnology, 20(3), 549-555.

Gerlach, L. (2007). Cow-pots: biodegradable pots for seedlings. http://blisstree.com/live/cowpotsbiod egradable-pots-for-seedlings/. Accessed November 2019. 
Godfrey, L. (2019). Waste plastic, the challenge facing developing countries-ban it, change it, collect it? Recycling, 4(1), 3-15.

Groh, K. J., Backhaus, T., Carney-Almroth, B., Geueke, B., Inostroza, P. A., Lennquist, A. \& Warhurst, A. M. (2019). Overview of known plastic packaging-associated chemicals and their hazards. Science of the total environment, 651, 3253-3268.

Guragain, Y. N., Herrera, A. I., Vadlani, P. V., \& Prakash, O. (2015). Lignins of bioenergy crops: a review. Natural product communications, 10(1), 1-14.

Hahladakisa, J. N., Costas, A. V., Weberb, R., Iacovidoua, E. \& Purnell, P. (2018). An overview of chemical additives present in plastics: Migration, release, fate and environmental impact during their use, disposal and recycling. Journal of Hazardous Materials, 344, 179-199.

Ingram, D. L. \& Nambuthiri, S. (2012). Using plantable containers for selected groundcover plant production. HortScience 47(9) (Supplement) 2012 SR-ASHS Annual Meeting February 3-6, 2012.

Kim, J. H., Kang, B. Y., Ryu, J., \& Nam, I. H. (2020). Effects on Pinus densiflora Seedlings as Affected by Different Container Growth Conditions. International Journal of Environmental Research and Public Health, 17(10), 35653572.

Macur, B. M, \& Pudlowski, Z. J. (2009). Plastic bags - a hazard for the environment and

Nyoka, B. I., Ajayi, O. C., Akinnifesi, F. K., Chanyenga, T., Mng' omba, S. A., Sileshi, G. \& Madhibha, T. (2011). Certification of agroforestry tree germplasm in Southern Africa: opportunities and challenges. Agroforestry systems, 83(1), 75-87.

Nzimande, N., Mutanga, O., Kiala, Z., \& Sibanda, M. (2020). Mapping the spatial distribution of the yellowwood tree (Podocarpus henkelii) in the Weza-Ngele forest using the newly launched Sentinel-2 multispectral imager data. South African Geographical Journal, 1, 1-19. a challenge for contemporary engineering educators. Journal of Education, Technology and Society, 7(2), 122-126.

Mng'omba, S. A., Akinnifesi, F. K., Sileshi, G., Ajayi, O. C., Chakeredza, S., \& Mwase, W. F. (2008). A decision support tool for propagating Miombo indigenous fruit trees of southern Africa. African Journal of Biotechnology, 7(25).

Moharam, R. \& Maqtari, M. A. A. (2014). The impact of plastic bags on the environment: A field survey of the city of Sana'a and the surrounding areas, Yemen. International Journal of Engineering Research and Reviews, 2(4), 6169.

Muriuki, J. K., Kuria, A. W., Muthuri, C.W., Mukuralinda A., Simons, A.J. \& Jamnadass, R.H. (2014). Testing Biodegradable Seedling Containers as an Alternative for Polythene Tubes in Tropical Small-Scale Tree Nurseries. Small-scale Forestry, 13,127-142.

Nechita, P., Dobrin, E., Ciolacu, F., \& Bobu, E. (2010). The biodegradability and mechanical strength of nutritive pots for vegetable planting based on lignocellulose composite materials. BioResources, 5(2), 1102-1113.

Negash, L. (1995). Indigenous Trees of Ethiopia: Biology, Uses and Propagation Techniques (pp. 125-147). Printed by the SLU Reprocentralen, Umea, Sweden.

Oguge, N. O. (2019). Circular Economy Measures: An Opportunity For Rethinking Plastics Waste Governance in Kenya. Law, Environment and Development (LEAD) Journal, 15, 124.

Ramaswamy, V, \& Sharma, H. R (2011). Plastic bags - threat to environment and cattle health: A retrospective study from Gondar city of Ethiopia. Applied Biochemistry Biotechnology Journal, 21, 712. 
Shabani, F., Kumar, L., \& Esmaeili, A. (2015). A modelling implementation of climate change on biodegradation of LowDensity Polyethylene (LDPE) by Aspergillus niger in soil. Global Ecology and Conservation, 4, 388-398.

Sitienei, P. C., Wagara, I. N., Kariuki, S. T., Jefwa, J. M. \& Kibiro, E. M. (2015). Occurrence and Biodiversity of Arbuscular Mycorrhizae Fungi associated with indeginous trees in Eastern Mau Forest, Kenya. Science Journal of Microbiology, 2015, 1-19.

The Kenya Gazette. 14 $4^{\text {th }}$ March 2017. http://kenyalaw.org/kenya_gazette/ga zette/notice/181293

Thompson, R. C., Moore, C. J., Vom Saal, F. S., \& Swan, S. H. (2009). Plastics, the environment and human health: current consensus and future trends. Philosophical Transactions of the Royal Society B: Biological Sciences, 364(1526), 2153-2166.

Turner-Skoff, J. B. \& Cavender, N. (2019). The benefits of trees for livable and sustainable communities. Plant, People,
Planet, $\quad$ 1: 323-335.

https://doi.org/10.1002/ppp3.39

UN Environment Programme. 5th June 2020. https://www.unep.org/news-andstories/story/kenya-bans-single-useplastics-protected-areas

Wang, X., Fernandez, T., Cregg, B., Fulcher, A., Geneve, R., Niu, G., Verlinden, S., Ngouajio. M., Kijchavengku, T., Auras, R., Bi, G., Nambuthiri, S. \& Conneway, R. (2012). Performance of Alternative Containers and Plant Growth and Water Use of Euonymus fortune. HortScience, 47(9), 2-10.

Yang, L., Sailesh, R., Jian-Chu, X., Xiao-Kun, O., Ying-Zai, Z., Jian-Fang, Y., Xun-Feng, W., Horst, W. \& Jun, H. (2016). Propagation of native tree species to restore subtropical evergreen broadleaved forests in S.W. China. Forest, 7(12), 1-14.

Zewdie, T. \& Welka K. (2015). Effect of micropyle orientation on germination of Millettia ferruginea and Delonix regia. Ecological processes, 4(12), 1-7 